\title{
On the Unique Microstructure and Properties of Ultra-High Carbon Bearing Steel Alloyed with Different Aluminum Contents
}

\author{
Jiaojiao Bai ${ }^{1,2}$, Wanli Zhang ${ }^{2}$, Yuhui Wang ${ }^{3}$, Cunyu Wang ${ }^{2}$, Xingpin Chen ${ }^{1}$, Zhiyue Shi ${ }^{2}$, Hui Wang ${ }^{2}$ \\ and Wenquan Cao ${ }^{2, *}$ \\ 1 College of Materials Science and Engineering, Chongqing University, Chongqing 400044, China; \\ m18798011462@163.com (J.B.); xpchen@cpu.edu.cn (X.C.) \\ 2 Special Steel Department, Central Iron and Steel Research Institute, Beijing 100081, China; \\ zhw1930613@163.com (W.Z.); wangcunyu@nercast.com (C.W.); b20190517@xs.ustb.edu.cn (Z.S.); \\ wanghui2018@cqu.edu.cn (H.W.) \\ 3 National Engineering Research Center for Equipment and Technology of Cold Rolled Strip, \\ Yanshan University, Qinhuangdao 066004, China; yhwang@ysu.edu.cn \\ * Correspondence: caowenquan@nercast.com
}

Citation: Bai, J.; Zhang, W.; Wang, Y.; Wang, C.; Chen, X.; Shi, Z.; Wang, H.; $\mathrm{Cao}, \mathrm{W}$. On the Unique

Microstructure and Properties of Ultra-High Carbon Bearing Steel Alloyed with Different Aluminum Contents. Metals 2021, 11, 1116. https://doi.org/10.3390/met11071116

Academic Editor: Marcello Cabibbo

Received: 17 June 2021

Accepted: 9 July 2021

Published: 12 July 2021

Publisher's Note: MDPI stays neutral with regard to jurisdictional claims in published maps and institutional affiliations.

Copyright: (C) 2021 by the authors. Licensee MDPI, Basel, Switzerland. This article is an open access article distributed under the terms and conditions of the Creative Commons Attribution (CC BY) license (https:/ / creativecommons.org/licenses/by/ $4.0 /)$.

\begin{abstract}
In this study, ultra-high-carbon steels with 1.4\% carbon content alloyed with three different aluminum contents, $2.0 \%, 4.0 \%$ and $6.0 \%$, were studied on their tempering stability and temperature resistance. The results showed that the addition of Al significantly enhanced the tempering stability and temperature resistance of ultra-high-carbon steel. The addition of $\mathrm{Al}$ inhibited the transformation of $\varepsilon$-carbide to cementite, suppressed the transition of martensite to ferrite and thus, endowed ultra-high carbon steels to maintain very high hardness during tempering within a wide range of temperature up to $500{ }^{\circ} \mathrm{C}$. The present work provides a useful basis on which to develop bearing steel materials with low density and high hardness.
\end{abstract}

Keywords: Al content; ultra-high-carbon steel; tempering stability; temperature resistance

\section{Introduction}

Ultra-high-carbon steels (UHCSs), which are hypereutectoid steels (1 to $2.1 \% \mathrm{C}$ ), have been studied extensively, owing to their unique mechanical properties [1-6]. UHCSs have high strength, high hardness and good abrasion resistance but are prone to form network carbides due to carbon segregation, leading to poor plasticity and high brittleness at room temperature $[7,8]$. However, when prepared by an appropriate process and alloying, UHCSs can be superplastic at elevated temperatures and exhibit high strength and good ductility at room temperature $[9,10]$. Such intriguing properties are attributed to the elimination of deleterious proeutectoid network carbides and the development of ultrafine carbides in spherical or pearlitic form [11-13]. Alloying elements of Al and Si were added to inhibit the precipitation of network carbides in the UHCSs. Due to both $\mathrm{Al}$ and Si being graphitized elements, it is necessary to add $\mathrm{Cr}$ to stabilize carbides and prevent the precipitation of graphite [14]. At present, the topics on UHCSs are mainly focused on how to obtain an ultrafine grained matrix, how to eliminate network carbides by alloying, superplasticity at elevated temperature and the influence of the spheroidized microstructure on room-temperature mechanical properties. It was revealed that the hardness of UHCS after quenching and tempering is over $65 \mathrm{HRC}$, which is significantly higher than that of conventional high-carbon bearing steel [4]. In addition, the strength, contact fatigue and wear resistance of the ultra-high-carbon steel are all better than that of the conventional high-carbon chromium-bearing steel [15-19]. The addition of Al significantly reduces the density of steels, due to lattice expansion and the replacement of Fe by $\mathrm{Al}$ [20-22]. However, at the present time, no detailed study has been demonstrated in the literature on 
the microstructure evolution during the tempering process, and no further research exists on the effects of aluminum content on the microstructure and properties of ultra-highcarbon steel, the lack of which hinders the research and application of ultra-high-carbon steel, especially in the bearing industry.

When quenched steel is tempered, the ability to resist decreases in strength and hardness is called tempering stability. Temperature resistance refers to the property of maintaining excellent mechanical properties under heated conditions. In order to examine the possibility of the application of ultra-high-carbon steel as a bearing steel, the effect of $\mathrm{Al}$ content on tempering stability and temperature resistance of ultra-high-carbon steel were investigated in this study. The addition of $\mathrm{Al}$ can effectively inhibit the precipitation of pre-eutectoid network carbides in ultra-high-carbon steel, but excessive addition will cause graphitization to occur, and it is detrimental to hot formability and hot workability. In the existing research, the $\mathrm{Al}$ content of ultra-high-carbon steel is generally selected to be $1.6 \sim 6 \%$. In order to study the effect of $\mathrm{Al}$ on ultra-high-carbon steel, $2 \%, 4 \%$, and $6 \% \mathrm{Al}$ is added. In addition, microstructure and hardness were compared and evaluated between the ultra-high-carbon steel and the conventional bearing steel of GCr15. Our aim in this research is to reveal the unique microstructure and properties of ultra-high-carbon-steel alloyed with aluminum and to demonstrate the possibility of the application of ultra-highcarbon steel as a promising bearing material with low density, ultra-high hardness and high temperature resistance.

\section{Experimental}

Three types of $1.4 \%$ C-UHCSs with different $\mathrm{Al}$ content were prepared by induction melting, cast into ingots and forged into bars with a $60 \mathrm{~mm}$ diameter. The GCr15 bearing steel for comparison was industrial steel produced by the Xingcheng Special Steel Company (Jiangyin, China).

With the addition of aluminum, the density of UHCS-6Al steel $\left(7.10 \mathrm{~g} / \mathrm{cm}^{3}\right)$ is $9 \%$ lighter than GCr15 steel $\left(7.81 \mathrm{~g} / \mathrm{cm}^{3}\right)$, while maintaining high hardness and good wearresistance [23].

The chemical compositions of these steels are listed in Table 1. Samples were cut from each bar. The metallographic samples of UHCSs were heated to different temperatures from $700{ }^{\circ} \mathrm{C}$ to $1000{ }^{\circ} \mathrm{C}$ for $30 \mathrm{~min}$ and then quenched with oil to room temperature. The quenched samples were treated at $-73^{\circ} \mathrm{C}$ for $2 \mathrm{~h}$ to reduce the retained austenite content. Finally, the cryogenic samples were tempered at different temperatures from $160{ }^{\circ} \mathrm{C}$ to $600{ }^{\circ} \mathrm{C}$ for $2 \mathrm{~h}$; a schematic diagram of the heat-treatment process is shown in Figure 1.

The microstructural study was carried out by scanning electron microscopy (SEM, FEI Quanta 650 FEG, FEI, Hillsboro, OR, USA) and transmission electron microscopy (TEM, H-800, HITACHI, Tokio, Japan), and the hardness in each case was obtained using a Rockwell hardness tester (TH-300, TIME, Guangzhou, China). Eight indentations were measured for each sample. In addition, the hardness of the samples tempered at $160{ }^{\circ} \mathrm{C}$ was tested after heating for $30 \mathrm{~min}$ at $200-500^{\circ} \mathrm{C}$ using a high-temperature hardness tester.

Table 1. Compositions of Ultra-High-Carbon Steels (UHCS) and GCr15 Bearing Steel (wt.\%).

\begin{tabular}{ccccccc}
\hline Materials & $\mathbf{C}$ & $\mathbf{S i}$ & $\mathbf{M n}$ & $\mathbf{C r}$ & $\mathbf{A l}$ & $\mathbf{F e}$ \\
\hline UHCS-2Al & 1.33 & 0.27 & 0.45 & 1.54 & 2.05 & Bal. \\
UHCS-4Al & 1.40 & 0.33 & 0.47 & 1.68 & 4.7 & Bal. \\
UHCS-6Al & 1.39 & 0.31 & 0.45 & 1.62 & 5.98 & Bal. \\
GCr15 & 1.0 & 0.25 & 0.35 & 1.5 & - & Bal. \\
\hline
\end{tabular}




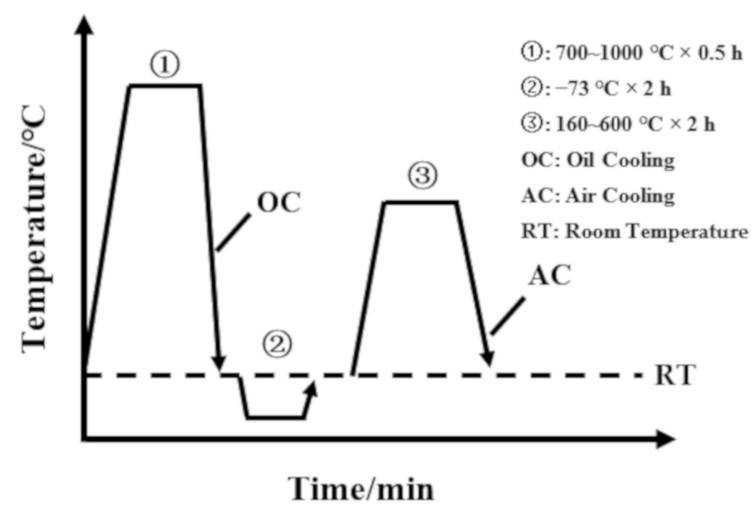

Figure 1. The schematic diagram of heat treatment process.

\section{Results and Discussion}

\subsection{Microstructures after Forging and Determination of Phase Transition Temperatures}

The microstructures of the UHCSs after forging are lamellar pearlites, as shown in Figure 2. The number and size of the grain boundary carbides decreased significantly with the increase in $\mathrm{Al}$ content, which indicated that the addition of $\mathrm{Al}$ could obviously inhibit the the network carbides. Because the addition of $\mathrm{Al}$ constrained the austenitizing process by suppressing the dissolution of carbides, undissolved carbides are likely to remain after austenitizing. The presence of undissolved carbides must reduce the concentration of solid solution carbon in austenitic matrices. Additionally, the carbon content of austenite decreased with the increase in Al content, which reduced the driving force for the precipitation of carbides and thus, lowered the precipitation of network carbides.
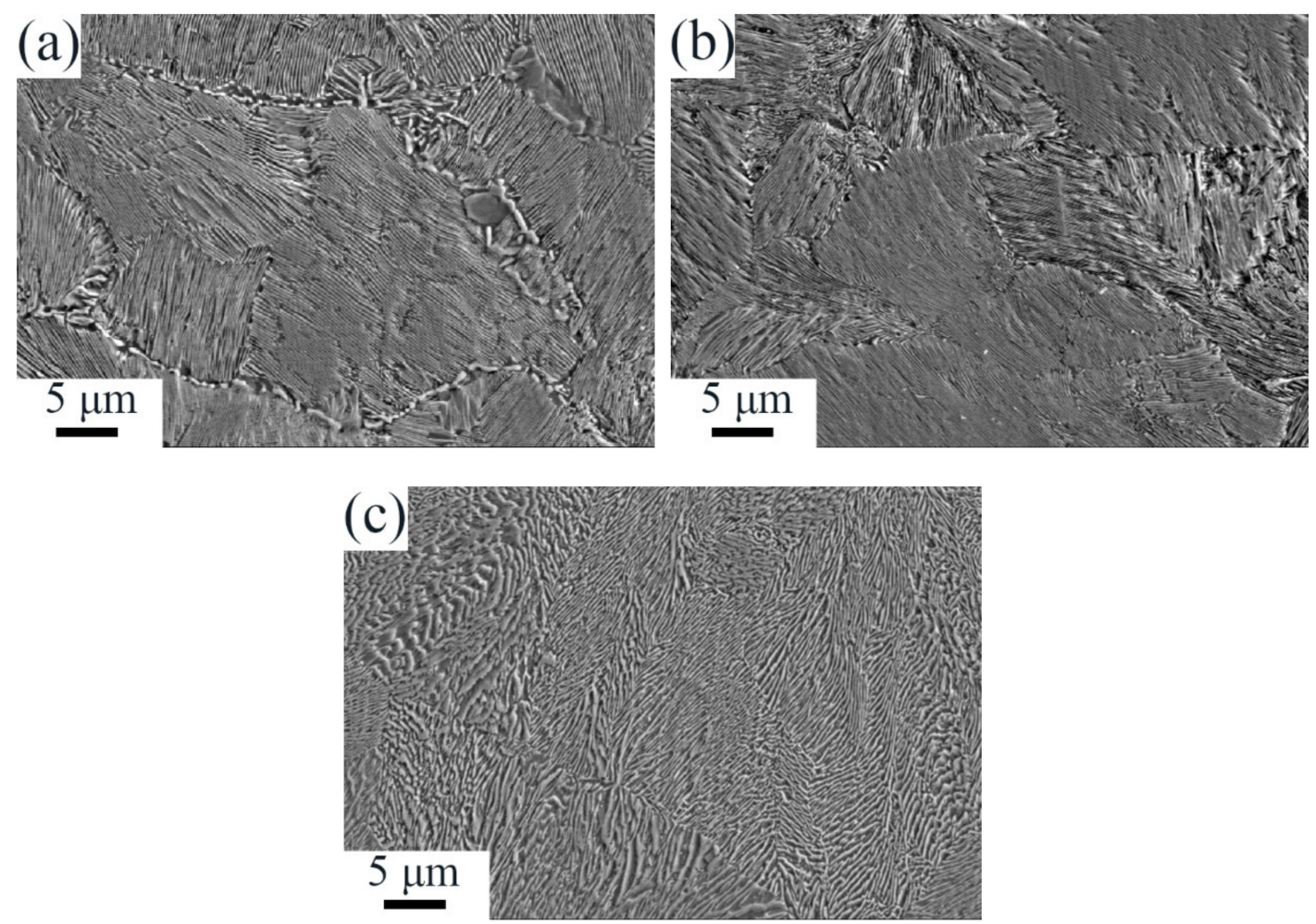

Figure 2. Microstructures of UHCSs (Ultra-high-carbon steels) with different Al contents, after forging. (a) UHCS-2Al, (b) UHCS-4Al, (c) UHCS-6Al. 
In order to design a suitable heat treatment process for UHCSs with different $\mathrm{Al}$ content, the phase transition temperature of the materials must be tested first. The phase transition temperature was simply measured by the quenching hardness method. The three types of UHCSs were quenched in oil after isothermal treatment at different temperatures in the range of $750-900{ }^{\circ} \mathrm{C}$ for $30 \mathrm{~min}$. Figure 3 shows the SEM microstructure of UHCS-2Al after quenching at different temperatures. The Rockwell hardness-temperature relationship curve of UHCS steel after austenitization + cryogenic treatment $+160^{\circ} \mathrm{C} \times 2 \mathrm{~h}$ tempering treatment is shown in Figure 4. The cryogenic treatment is to reduce the content of retained austenite. Among them, Q represents oil-cooled; CT represents cryogenic treatment, and T represents tempered.

Austenizing occurred partly when heated at $800^{\circ} \mathrm{C}$, and the microstructure of quenched UHCS-2Al was a mixture of martensite and pearlite, as shown in Figure $3 \mathrm{c}$. When the heating temperature reached $825^{\circ} \mathrm{C}$, the quenching microstructure was ultrafine martensite, as shown in Figure $3 \mathrm{~d}$. The martensite grains grew remarkably when the quenching temperature exceeded $900{ }^{\circ} \mathrm{C}$, and the microstructure is composed of lath martensite and acicular martensite, as shown in Figure 3f.

For UHCS-2Al, the hardness after different quenching temperatures is shown in the black curve in Figure $4 \mathrm{a}$. It is clear that there is a plateau with small fluctuations in hardness value before $775^{\circ} \mathrm{C}$. After that, hardness sharply increases and reaches its peak value at $825^{\circ} \mathrm{C}$. The beginning and end of the sharp increase of hardness both correspond to the start and completion of austenitization, respectively. With further increases in the quenching temperature, hardness gradually decreases, which is due to the coarseness of the martensite grains. Therefore, the $\mathrm{Ac}_{1}$ and $\mathrm{Ac}_{3}$ of UHCS-2Al are roughly determined to be $775{ }^{\circ} \mathrm{C}$ and $825^{\circ} \mathrm{C}$, respectively. Using the same method, the $\mathrm{Ac}_{1}$ and $\mathrm{Ac}_{3}$ of UHCS-4Al are evaluated to be $800{ }^{\circ} \mathrm{C}$ and $850{ }^{\circ} \mathrm{C}$, respectively; the $\mathrm{Ac}_{1}$ and $\mathrm{Ac}_{3}$ of UHCS-6Al are evaluated to be $825^{\circ} \mathrm{C}$ and $875^{\circ} \mathrm{C}$, respectively, as shown in the black curves in Figure $4 \mathrm{a}$.

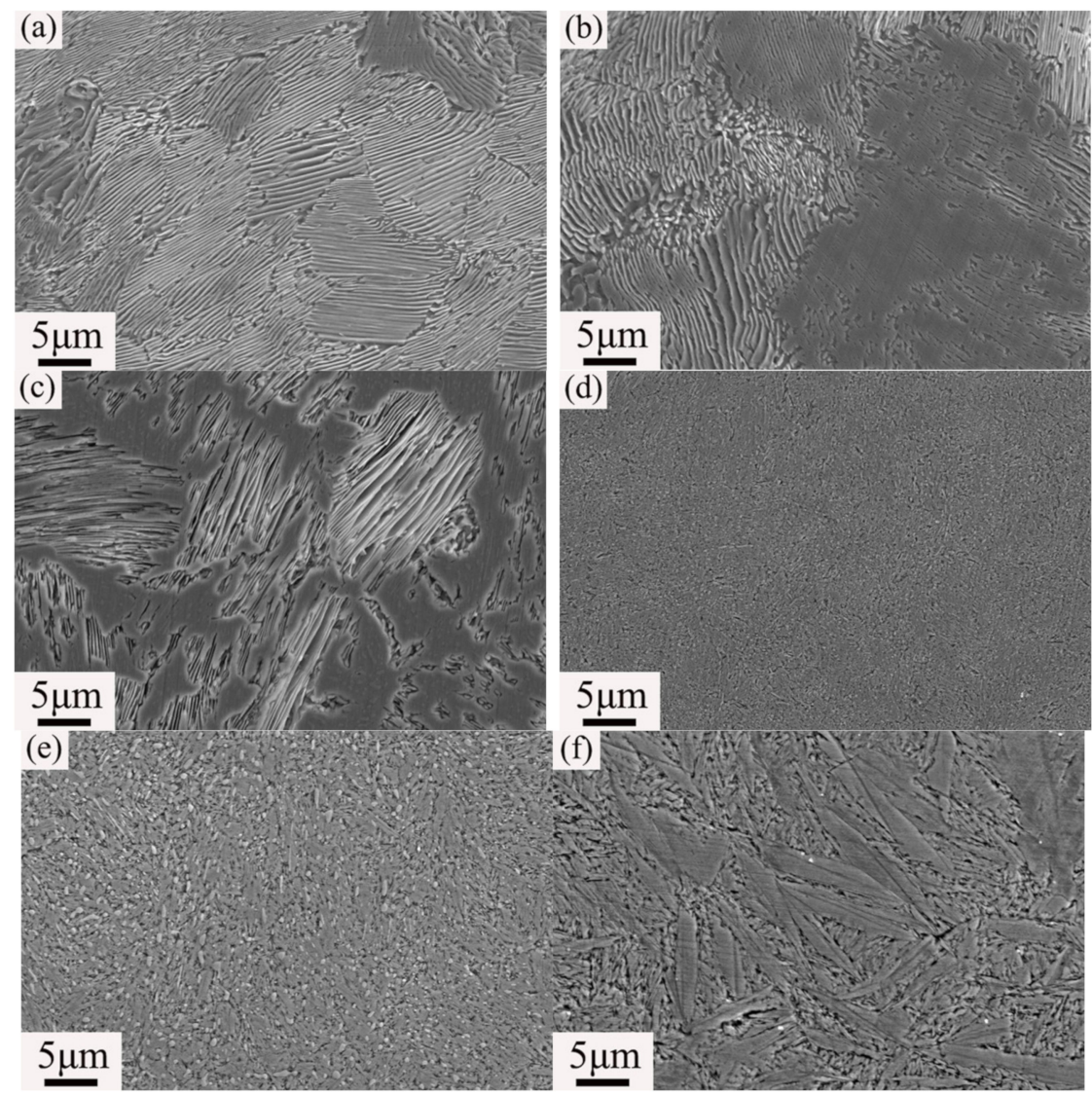

Figure 3. Microstructure of UHCS-2Al quenched at different temperatures. (a) $750{ }^{\circ} \mathrm{C},\left(\right.$ b) $775{ }^{\circ} \mathrm{C}$, (c) $800{ }^{\circ} \mathrm{C}$, (d) $825^{\circ} \mathrm{C},\left(\right.$ e) $850{ }^{\circ} \mathrm{C},\left(\right.$ f) $900{ }^{\circ} \mathrm{C}$. 

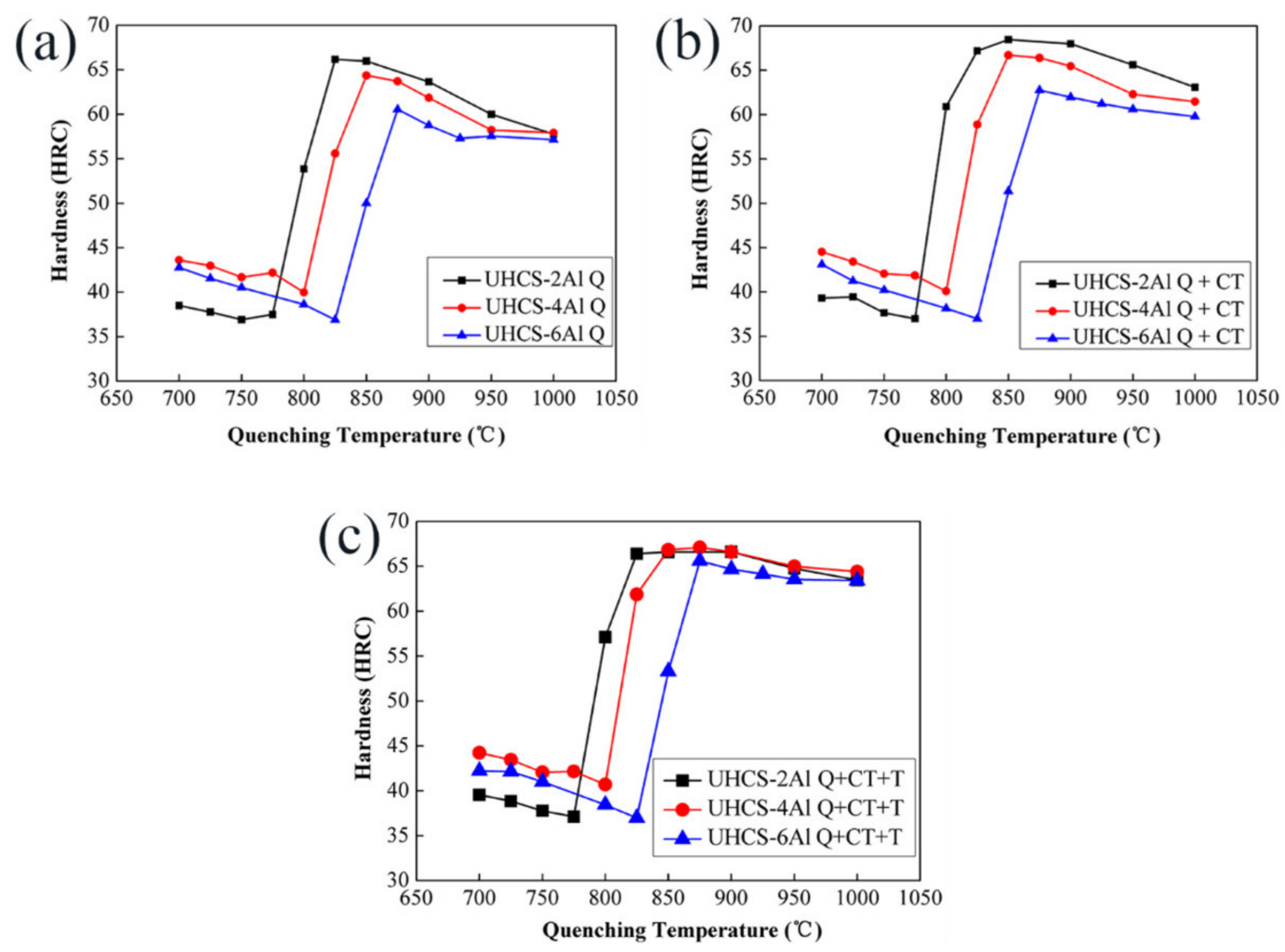

Figure 4. Hardness of UHCSs with different Al content under different experimental conditions: (a) Quenching hardness, (b) cryogenic treatment hardness, (c) tempering hardness.

According to Figure 4c, UHCS-2Al, UHCS-4Al and UHCS-6Al have austenitized at $825^{\circ} \mathrm{C}, 850{ }^{\circ} \mathrm{C}$ and $875^{\circ} \mathrm{C}$, respectively. The peak hardness of the tempered samples with different $\mathrm{Al}$ content is between 65-68 HRC. The super-high hardness of UHCSs was beneficial to the wear-resistance and contact-fatigue properties. Examining Figure $4 b, c$, it is worth noting that the hardness of cryogenic-treated UHCS-2Al steel decreased after tempering, whereas that of UHCS-4Al and UHCS-6Al steels anomalously increased. This indicated that the addition of $\mathrm{Al}$ could effectively inhibit the softening of tempering and even increase the hardness of the steel. In addition, the higher the Al content, the more the hardness increases.

\subsection{Tempering Stability and Temperature Resistance}

Based on the above results, three types of UHCSs and GCr15-bearing steel were treated by quenching, cryogenic treatment and tempering at different temperatures to explore the effect of $\mathrm{Al}$ content on tempering stability. After the heat treatment, the hardness of the sample was measured, as shown in Figure 5 (Note: tempering at $20^{\circ} \mathrm{C}$ indicates the cryogenic treatment).

The hardness of GCr15 steel was $62 \mathrm{HRC}$ after being tempered at $200{ }^{\circ} \mathrm{C}$. When the tempering temperature exceeded $200{ }^{\circ} \mathrm{C}$, the tempering hardness decreased continuously with increasing tempering temperature. The hardness of UHCSs with Al content was stable at higher levels (63-65 HRC) within a certain temperature range. For UHCS-2Al steel, the tempered hardness slowly decreased between $200 \sim 360^{\circ} \mathrm{C}$, but the decrease was small, and it was basically maintained at a relatively high level. The hardness of UHCS-4Al steel and UHCS-6Al steel remained basically unchanged with the increase in tempering temperature in the range of $200 \sim 400{ }^{\circ} \mathrm{C}$. Only when the tempering temperature exceeded the temperature range did the hardness begin to decrease with increasing tempering temperature. This indicated that the addition of $\mathrm{Al}$ inhibited the decomposition of martensite, endowing the UHCSs with good tempering stability. 


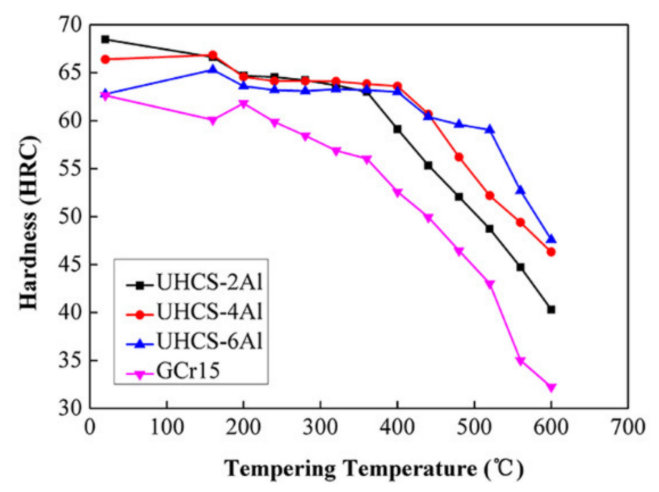

Figure 5. Hardness of UHCSs and GCr15 tempered at different temperatures.

The high-temperature hardness of three types of UHCSs was tested. UHCS-2Al, UHCS-4Al and UHCS-6Al were quenched at 850,875 and $900{ }^{\circ} \mathrm{C}$, respectively, after cryogenic treatment and tempered at $160{ }^{\circ} \mathrm{C}$ for $2 \mathrm{~h}$. The samples were tested using a high-temperature hardness tester at 200,300, 400 and $500{ }^{\circ} \mathrm{C}$ after being heated for $30 \mathrm{~min}$, and the test result is shown in Figure 6, indicating that the three types of UHCSs with Al content had good temperature resistance. The hardness was still maintained at a high level ( $>58 \mathrm{HRC}$ ) when UHCS-2Al steel was heated at $400{ }^{\circ} \mathrm{C}$ for $30 \mathrm{~min}$ and when UHCS-4Al steel and UHCS-6Al steel were heated at $500{ }^{\circ} \mathrm{C}$ for $30 \mathrm{~min}$. This greatly enhanced the potential of ultra-high-carbon steel with $\mathrm{Al}$ content as high-temperature bearing steel.

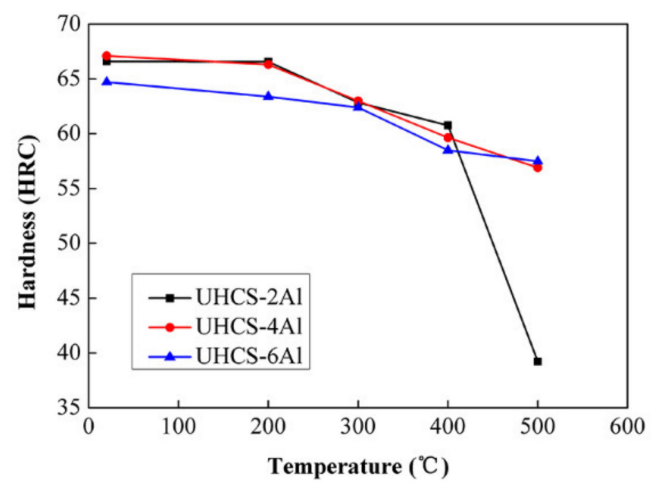

Figure 6. Hardness of UHCSs at high temperatures.

The addition of $\mathrm{Al}$ greatly improved the tempering stability and temperature resistance of ultra-high-carbon steel, and the higher the content of $\mathrm{Al}$, the more significant the effect was. It was preliminarily considered that the addition of Al greatly inhibited the decomposition of martensite. In order to further verify the above conjecture, the microstructures of three types of UHCSs and GCr15 steels after tempering at different temperatures were observed by SEM. Figures 7-10 show the microstructures of GCr15, UHCS-2Al, UHCS-4Al and UHCS-6Al steel, respectively, after tempering in the range $160-600{ }^{\circ} \mathrm{C}$.

Figure 5 shows that the hardness of GCr15 steel decreased relatively slowly when tempering below $360^{\circ} \mathrm{C}$, and the hardness remained at approximately $56 \mathrm{HRC}$ after tempering at $360^{\circ} \mathrm{C}$, indicating that the martensite microstructure was not completely decomposed. Figure 7a did not show obvious granular carbide precipitation on the martensite matrix after the GCr15 steel was tempered at $160^{\circ} \mathrm{C}$. Therefore, there is only a small decrease in hardness after a low-tempering temperature, as shown in Figure 5. Figure $7 \mathrm{~b}-\mathrm{d}$ shows the microstructures of tempering in the range $200-360{ }^{\circ} \mathrm{C}$, indicating that the martensite microstructure did not completely decompose, and some granular carbides precipitated on the martensitic matrix and the microstructure after tempering were tempered martensite and granular carbides, as shown by the yellow arrow in Figure 7. Figure 7e-j shows the 
microstructures of tempering in the range $400-600{ }^{\circ} \mathrm{C}$. In this temperature range, with the increasing tempering temperature, the tempering martensite decomposed into ferrite and carbides, and the amount of precipitated granular carbides increased and began to spheroidize gradually until completion. With increasing tempering temperature, carbide precipitation increased gradually. The martensitic microstructure decomposed continuously; the carbon content in the matrix continued to decrease, resulting in a continuous decrease in hardness. It was also the main reason why GCr15 bearing steel could not meet the conditions of high-temperature service.
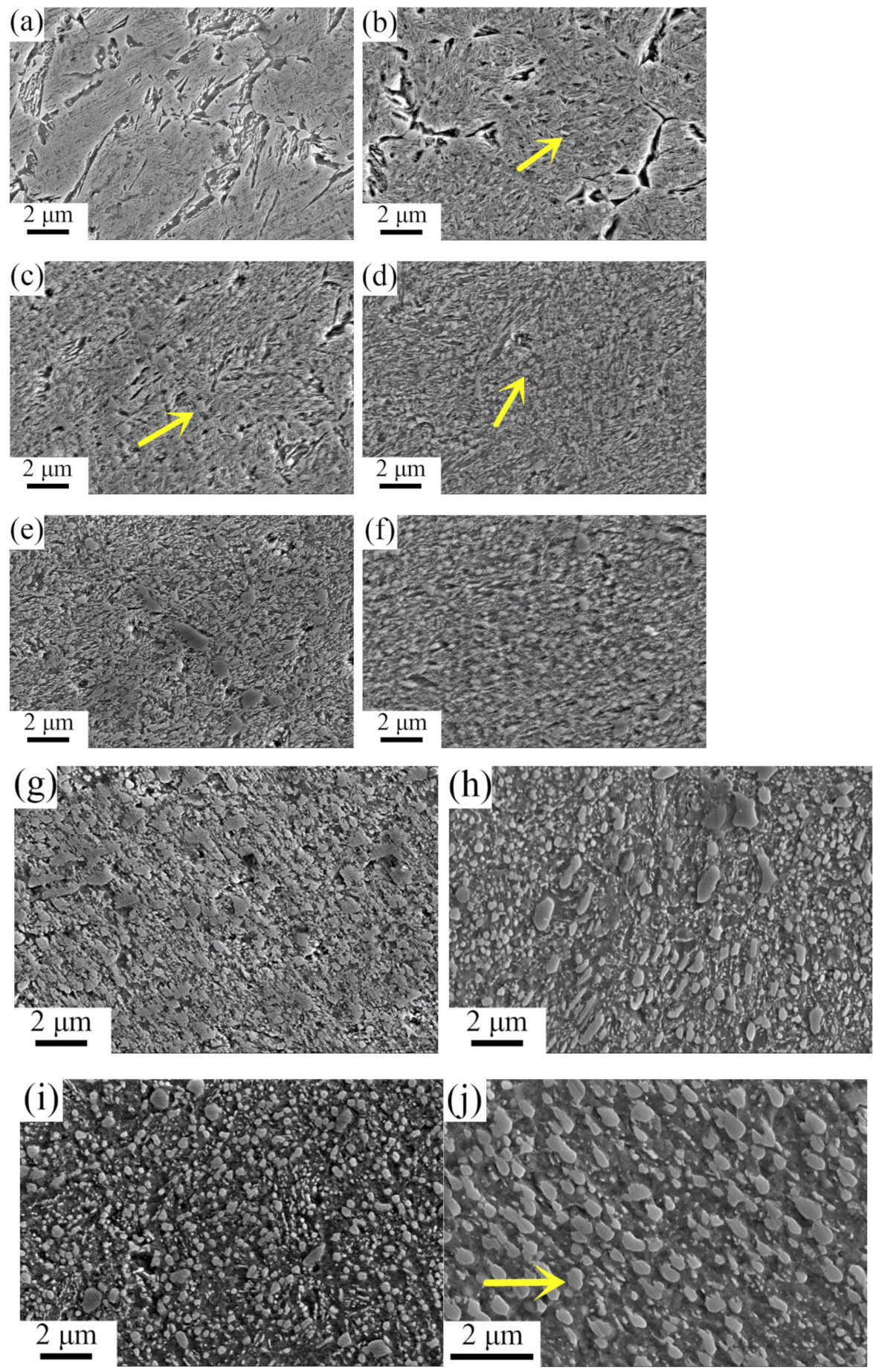

Figure 7. Microstructure of GCr15 after tempering at different temperatures. (a) $160{ }^{\circ} \mathrm{C},(\mathbf{b}) 200{ }^{\circ} \mathrm{C}$, (c) $280{ }^{\circ} \mathrm{C}$, (d) $360{ }^{\circ} \mathrm{C}$, (e) $400{ }^{\circ} \mathrm{C}$, (f) $440{ }^{\circ} \mathrm{C}$, (g) $480{ }^{\circ} \mathrm{C}$, (h) $520{ }^{\circ} \mathrm{C}$, (i) $560{ }^{\circ} \mathrm{C}$, (j) $600{ }^{\circ} \mathrm{C}$. 

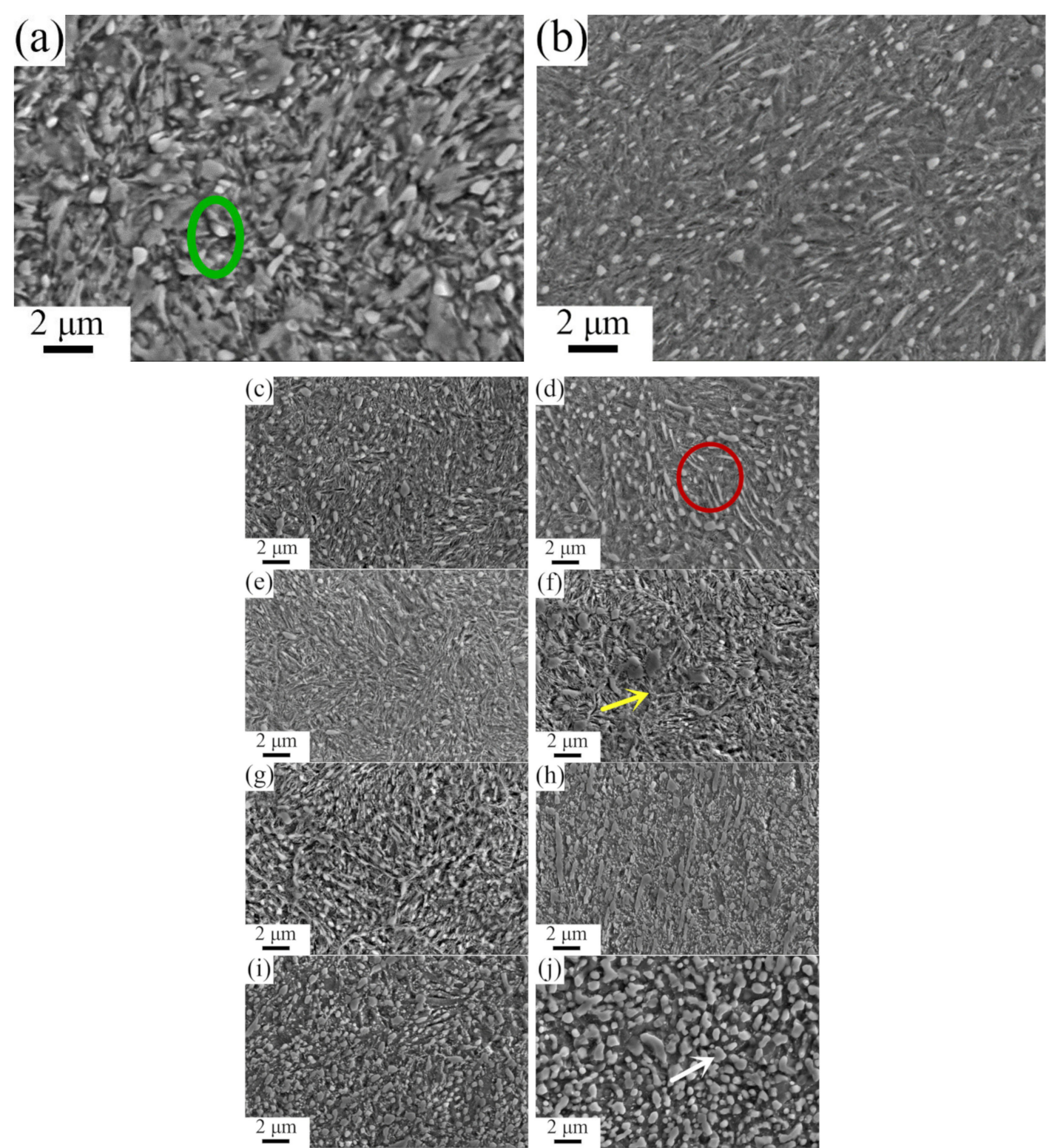

Figure 8. Microstructure of UHCS-2Al after tempering at different temperatures. (a) $160{ }^{\circ} \mathrm{C},(\mathbf{b}) 200^{\circ} \mathrm{C},(\mathbf{c}) 280{ }^{\circ} \mathrm{C},(\mathbf{d}) 320^{\circ} \mathrm{C}$, (e) $360{ }^{\circ} \mathrm{C}$, (f) $400{ }^{\circ} \mathrm{C}$, (g) $440{ }^{\circ} \mathrm{C}$, (h) $520^{\circ} \mathrm{C}$, (i) $560{ }^{\circ} \mathrm{C}$, (j) $600{ }^{\circ} \mathrm{C}$.

Figure 8a shows that UHCS-2Al steel was tempered martensite after tempering at $160{ }^{\circ} \mathrm{C}$ with a small amount of undissolved carbide particles in the quenching process, as shown by the carbide in the green circle in the picture, which are the same as the carbide in Figure 2a. When tempering in the temperature range $200-360^{\circ} \mathrm{C}$, as shown in Figure $8 \mathrm{~b}-\mathrm{e}$, martensite did not decompose and the number of carbide particles did not obviously increase, thus high hardness was maintained after tempering in this temperature range. When the tempering temperature exceeded $360^{\circ} \mathrm{C}$, martensite began to decompose into ferrite and cementite, and the number of cementite particles increased. When tempering in the range $400-440^{\circ} \mathrm{C}$, as shown in Figure $8 \mathrm{f}$, $\mathrm{g}$, obviously grain boundary carbides appeared, as shown by the yellow arrow, and the grain boundary network disappeared after further increases in the tempering temperature. With the tempering temperature further increased to $520-560{ }^{\circ} \mathrm{C}$, as shown in Figure $8 \mathrm{~h}, \mathrm{i}$, carbide, as shown by the white arrow, began to spheroidize, and spheroidization was almost complete after tempering at $600{ }^{\circ} \mathrm{C}$, as shown in Figure 8i. 


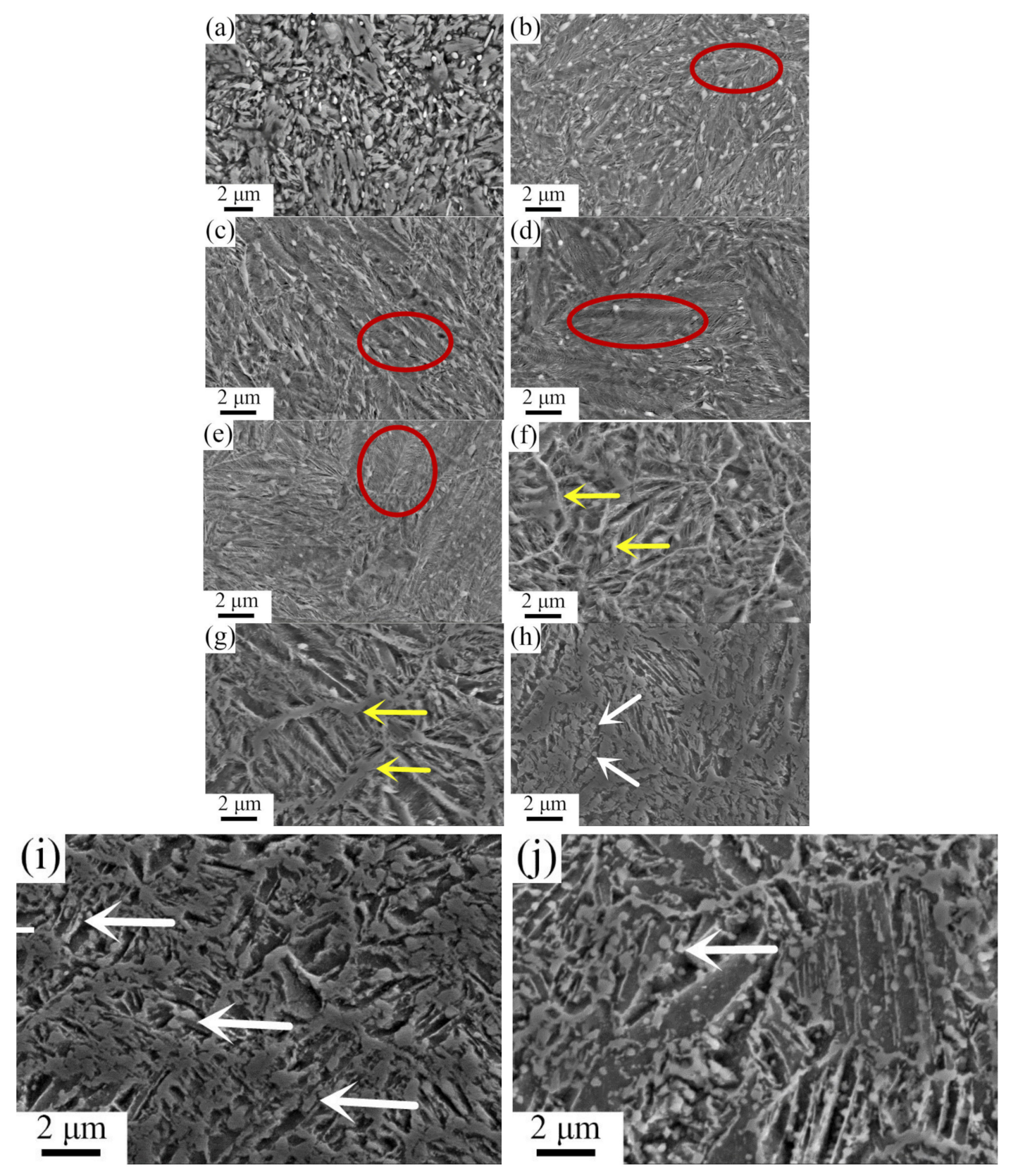

Figure 9. Microstructure of UHCS-4Al after tempering at different temperatures. (a) $160{ }^{\circ} \mathrm{C},(\mathbf{b}) 200^{\circ} \mathrm{C},(\mathbf{c}) 280^{\circ} \mathrm{C},(\mathrm{d}) 320^{\circ} \mathrm{C}$, (e) $400{ }^{\circ} \mathrm{C},(\mathbf{f}) 440{ }^{\circ} \mathrm{C},(\mathrm{g}) 480{ }^{\circ} \mathrm{C}$, (h) $520^{\circ} \mathrm{C}$, (i) $560{ }^{\circ} \mathrm{C}$, (j) $600{ }^{\circ} \mathrm{C}$.

As shown in Figure 9, the granular carbides on the martensitic matrix did not increase after UHCS-4Al steel was tempered in the range $200-400{ }^{\circ} \mathrm{C}$, indicating that there were no or only a few cementite particles precipitated. After tempering in this region, the tempering martensite morphology was obviously different from that of GCr15 steel. When UHCS-4Al steel was tempered in the range $200-400{ }^{\circ} \mathrm{C}$, there was a very fine needle carbide precipitate, densely distributed on martensite lath, as shown in the red circle in Figure 9b-e. It was preliminarily considered that the unstable $\varepsilon$-carbides, which were in coherence with the martensitic matrix, precipitated during the tempering process, which will be confirmed later. The $\varepsilon$-carbides were not transformed into cementite particles in this temperature range; therefore, UHCSs with $\mathrm{Al}$ content exhibited high hardness after tempering in this temperature range. The microstructure of UHCSs was analyzed in detail by TEM. When tempering temperature exceeded $400{ }^{\circ} \mathrm{C}$, the tempered martensite began to decompose, forming a grain boundary network, as shown by the yellow arrow in Figure 9f,g. With further increases in tempering temperature, granular carbides precipitated and grew, as 
shown by the white arrow in Figure 9h,j; however, the spheroidizing process for UHCS-4Al steel was not complete until the tempering temperature reached $600{ }^{\circ} \mathrm{C}$.
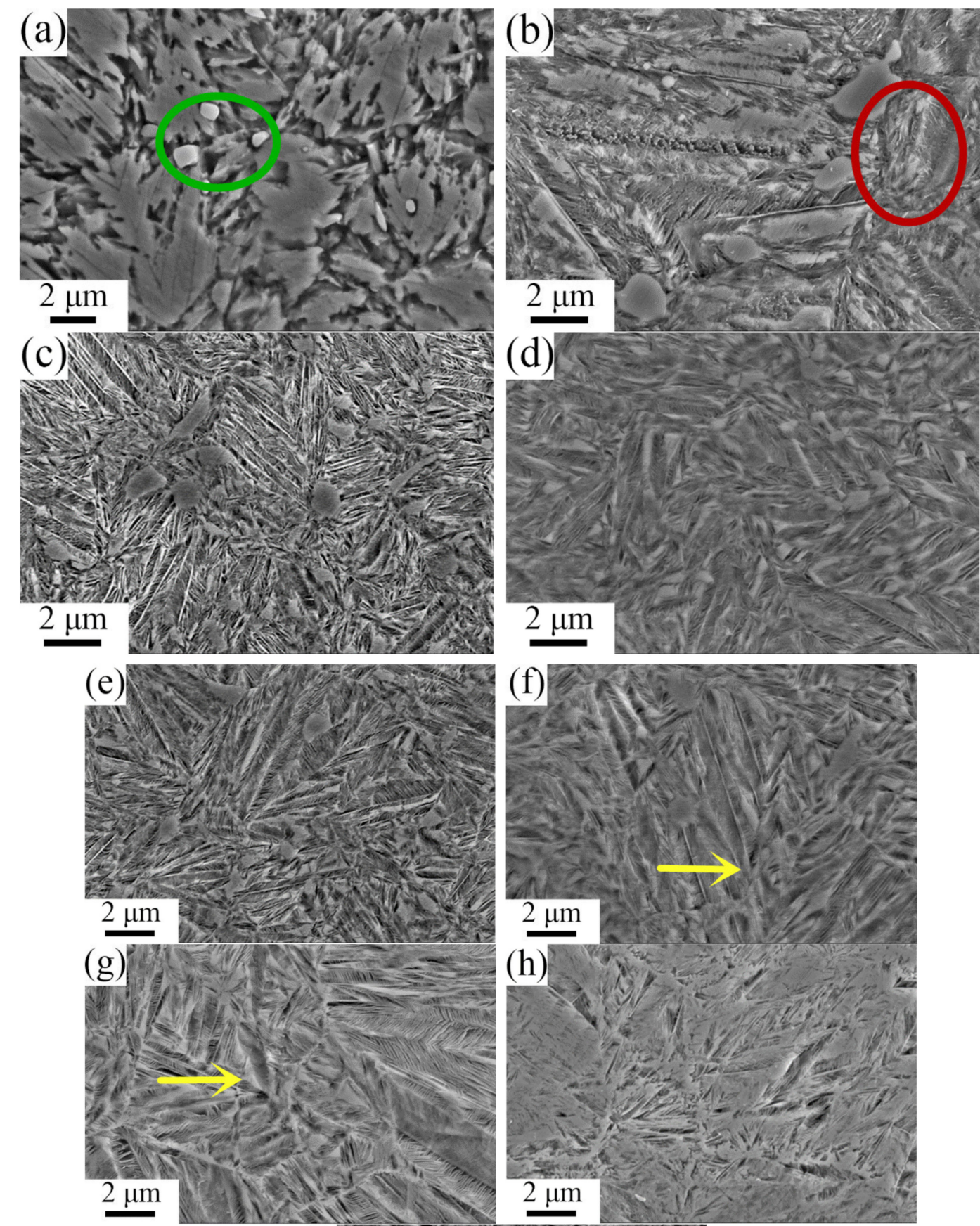

(h)

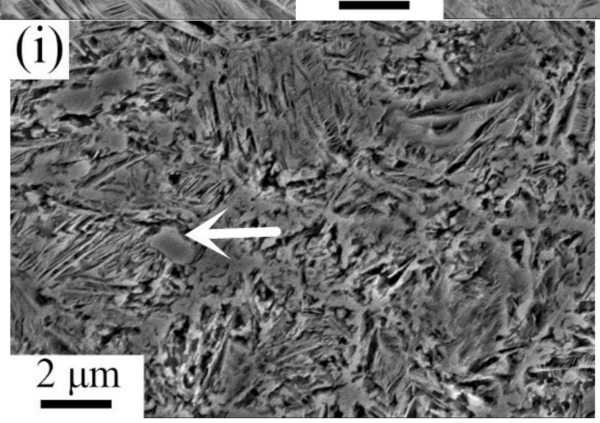

Figure 10. Microstructure of UHCS-6Al after tempering at different temperatures. (a) $160{ }^{\circ} \mathrm{C}$, (b) $200{ }^{\circ} \mathrm{C},\left(\right.$ c) $280{ }^{\circ} \mathrm{C}$, (d) $320^{\circ} \mathrm{C}$, (e) $400{ }^{\circ} \mathrm{C}$, (f) $440{ }^{\circ} \mathrm{C}$, (g) $480{ }^{\circ} \mathrm{C}$, (h) $520^{\circ} \mathrm{C}$, (i) $560{ }^{\circ} \mathrm{C}$. 
As shown in Figure 10, the microstructure of UHCS-6Al steel after tempering in the temperature range $200-520^{\circ} \mathrm{C}$ was similar to that of UHCS-4Al steel after tempering in the temperature range $200-400{ }^{\circ} \mathrm{C}$. During the tempering temperature at $160-440{ }^{\circ} \mathrm{C}$, as shown in Figure 10a-e, the microstructure maintained a martensitic microstructure instead of decomposing into ferrite and cementite. The very fine acicular carbides precipitated along the perpendicular direction to the martensitic lath beam, and no obvious cementite particles precipitated, as shown by the yellow arrow in Figure 10f,g. Due to the conversion of metastable $\varepsilon$-carbide to cementite, the hardness of UHCS-6Al steel was retained above $59 \mathrm{HRC}$ after tempering at $520{ }^{\circ} \mathrm{C}$. The addition of $\mathrm{Al}$ inhibited the $\varepsilon$ carbides, which were transformed into granular carbides, and very little granular cementite was formed. When the tempering temperature continues to rise, to $560^{\circ} \mathrm{C}$, a small amount of granular cementite can be seen, as shown by the white arrow in Figure 10i.

In essence, the microstructural transformation of high-carbon steel during tempering is divided into several stages. The microstructure of high-carbon steel before tempering was martensite (over the saturated alpha phase) and retained austenite (or partly undissolved carbides). During the tempering process, the temperature range $20-100{ }^{\circ} \mathrm{C}$ was the inoculation period. In this temperature region, the $\mathrm{C}$ atoms still had some diffusion ability, and the main process was the segregation and aggregation of $\mathrm{C}$ atoms. In the range $100-200{ }^{\circ} \mathrm{C}$, the main process was the decomposition of the quenched martensite, i.e., the $\mathrm{C}$ atoms from the oversaturated martensite that had dissolved, precipitating the unstable $\varepsilon$-carbides $\left(\mathrm{Fe}_{x} \mathrm{C}\left(\mathrm{Fe}_{2} \mathrm{C}, \mathrm{Fe}_{2.4} \mathrm{C}\right.\right.$, and $\left.\mathrm{Fe}_{2 \sim 3} \mathrm{C}\right)$, which were in coherence with the martensitic matrix, decreasing the $C$ content, lattice constant $C$ and square degree (c/a ratio) in martensite. In the temperature range $200-350{ }^{\circ} \mathrm{C}$, the main process was the transition of carbide type, namely, the $\varepsilon$-carbides or $\chi$-carbides $\left(\mathrm{Fe}_{5} \mathrm{C}_{2}\right.$, metastable carbides, which were converted from the $\varepsilon$-carbides at $>250{ }^{\circ} \mathrm{C}$ ) transforming into granular cementites. When the tempering temperature reached higher than $350^{\circ} \mathrm{C}$, the main process was the recovery and recrystallization of the alpha phase and the spheroidization and coarsening of cementites. With increasing tempering temperature, cementites aggregated, grew and gradually converted into spherical particles, and the $\alpha$-Fe recrystallized and gradually transformed from strip to equiaxed block.

In view of the changes in the microstructures of tempered GCr15 and UHCSs with aluminum content as shown in Figures 7-10, when UHCSs and GCr15 were tempered at $160^{\circ} \mathrm{C}$, the main process was the decomposition of the quenched martensite, i.e., the $\mathrm{C}$ atoms from the oversaturated martensite and the unstable nanoscale $\varepsilon$-carbides, which were in coherence with the martensitic matrix precipitated, dissolved and the quenched martensite transformed into tempered martensite. When GCr15 steel was tempered in the range $200-360^{\circ} \mathrm{C}$, the unstable $\varepsilon$-carbides gradually transformed into granular cementites. When the tempering temperature was more than $360^{\circ} \mathrm{C}$ for $\mathrm{GCr} 15$ steel, with further increasse in tempering temperature, cementites aggregated, grew and gradually converted into spherical particles, and the tempering martensite (alpha phase) further decarbonized and transformed into the ferrite phase, and the ferrite phase recrystallized and gradually transformed from strip to equiaxed block. However, UHCSs with Al content, such as UHCS-2Al, UHCS-4Al, and UHCS-6Al steels, were tempered in the ranges $200-360^{\circ} \mathrm{C}$, $200-400{ }^{\circ} \mathrm{C}$ and $200-520^{\circ} \mathrm{C}$, respectively, and there was no obvious conversion of unstable $\varepsilon$-carbides into granular cementites with increasing tempering temperature and prolonged tempering time (no significant increase in granular cementites was observed in the SEM microstructure). Studies [24] have shown that $\mathrm{Al}$ increases the eutectoid temperature and carbon content of the eutectoid point of steel, and the increase of the carbon content point of the test steel could make more carbon elements a solid solution in the matrix, thereby inhibiting the segregation of carbides. The addition of a high content of $\mathrm{Al}$ prevented the precipitation of cementite and promoted the formation of $\mathrm{k}$ carbides. The conversion process of $\varepsilon$-carbide to cementite was suppressed, which improved the tempering stability of $\varepsilon$-carbide. Until the tempering temperature further improved, the cementites precipitated obviously, i.e., $\varepsilon$-carbides began to transform into cementites, and tempering martensite 
began to transform into ferrite because of further decarbonization. With the further increase in tempering temperature, cementites aggregated, grew, and gradually converted into spherical particles, and the alpha-Fe recrystallized and gradually transformed from strip to equiaxed block.

The addition of $\mathrm{Al}$ inhibited or delayed the unstable nanoscale $\varepsilon$-carbides, which were in coherence with the martensitic matrix to transform into cementites, leading to the failure of the martensite to decarbonize to form the ferrite. Therefore, a hardness platform was formed in a certain tempering temperature range; therefore, the UHCSs with $\mathrm{Al}$ content exhibited high hardness after a relatively high-temperature tempering and had good temperature resistance. This was the basic reason for the high tempering stability and good temperature resistance of ultra-high-carbon steel due to the addition of aluminum. Moreover, with increasing $\mathrm{Al}$ content, the tempering stability and temperature resistance improved.

Figures 11-13 show the morphology and diffraction pattern of UHCSs with aluminum content after tempering using a transmission electron microscope (TEM). Through diffraction calibration, it can be determined that the needle-shaped carbides in the picture are $\varepsilon$-carbides (six square structure), as shown in the red circle in Figure 12a-c. Clearly, when UHCS-2Al steel was tempered in the ranges $160-360^{\circ} \mathrm{C}$, as shown in Figure $11 \mathrm{a}$, b, when UHCS-4Al steel was tempered in the ranges $160-400^{\circ} \mathrm{C}$, as shown in Figure $12 \mathrm{a}-\mathrm{C}$ and when UHCS-6Al steel was tempered in the ranges $160-520^{\circ} \mathrm{C}$ as shown in Figure 13a-e, the nanoscale carbides $\varepsilon$-carbides did not decompose, thus fully validating our view. In UHCS-4Al, when the tempering temperature was $480{ }^{\circ} \mathrm{C}, \varepsilon$-carbides decreased and turned into other types of carbides, as shown by the yellow circle in Figure 12d; the same microstructure can be seen in Figures 11c and 13f.
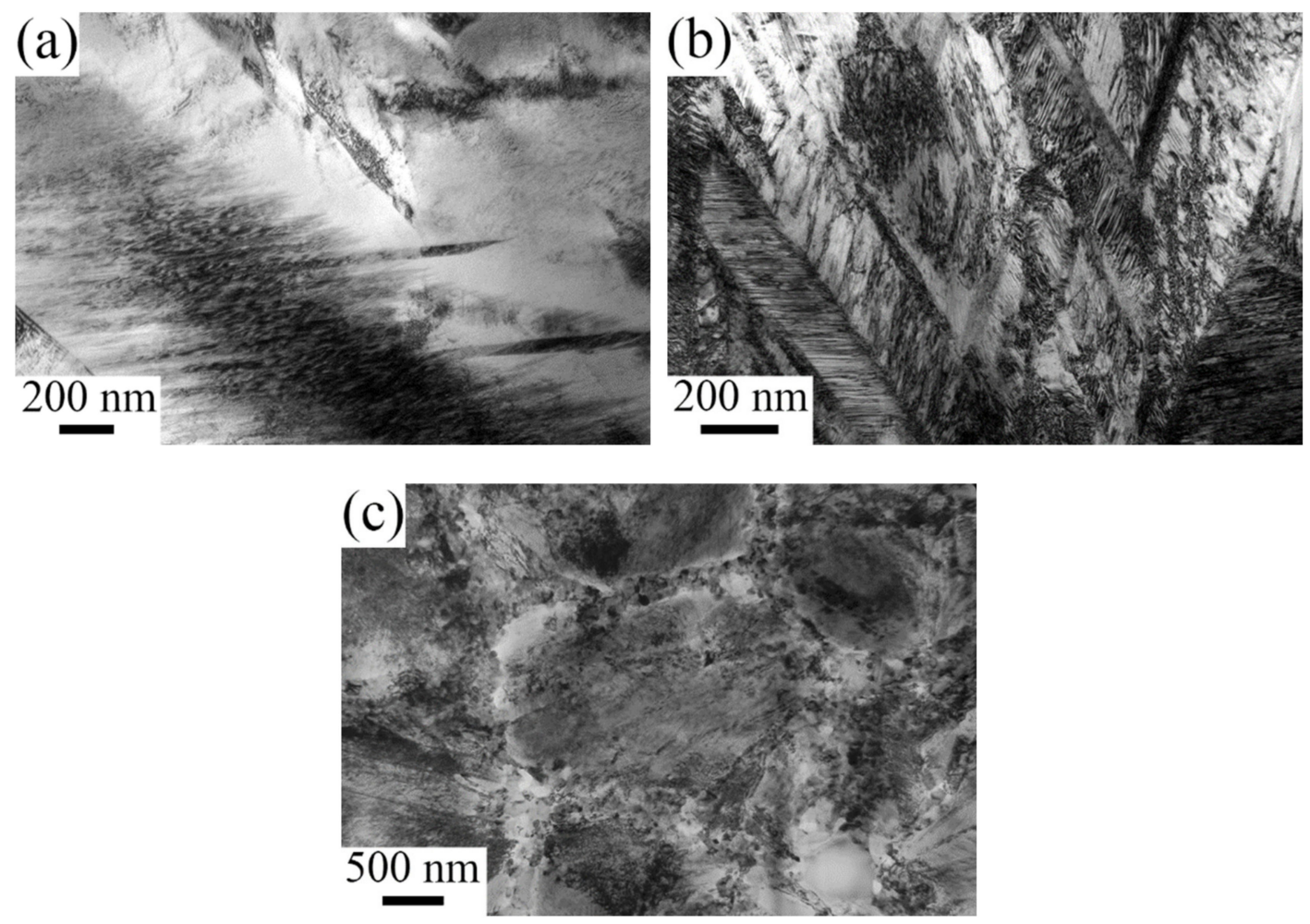

Figure 11. TEM (transmission electron microscope) microstructure of UHCS-2Al after tempering at different temperatures. (a) $160{ }^{\circ} \mathrm{C},(\mathbf{b}) 360^{\circ} \mathrm{C},(\mathbf{c}) 440{ }^{\circ} \mathrm{C}$. 

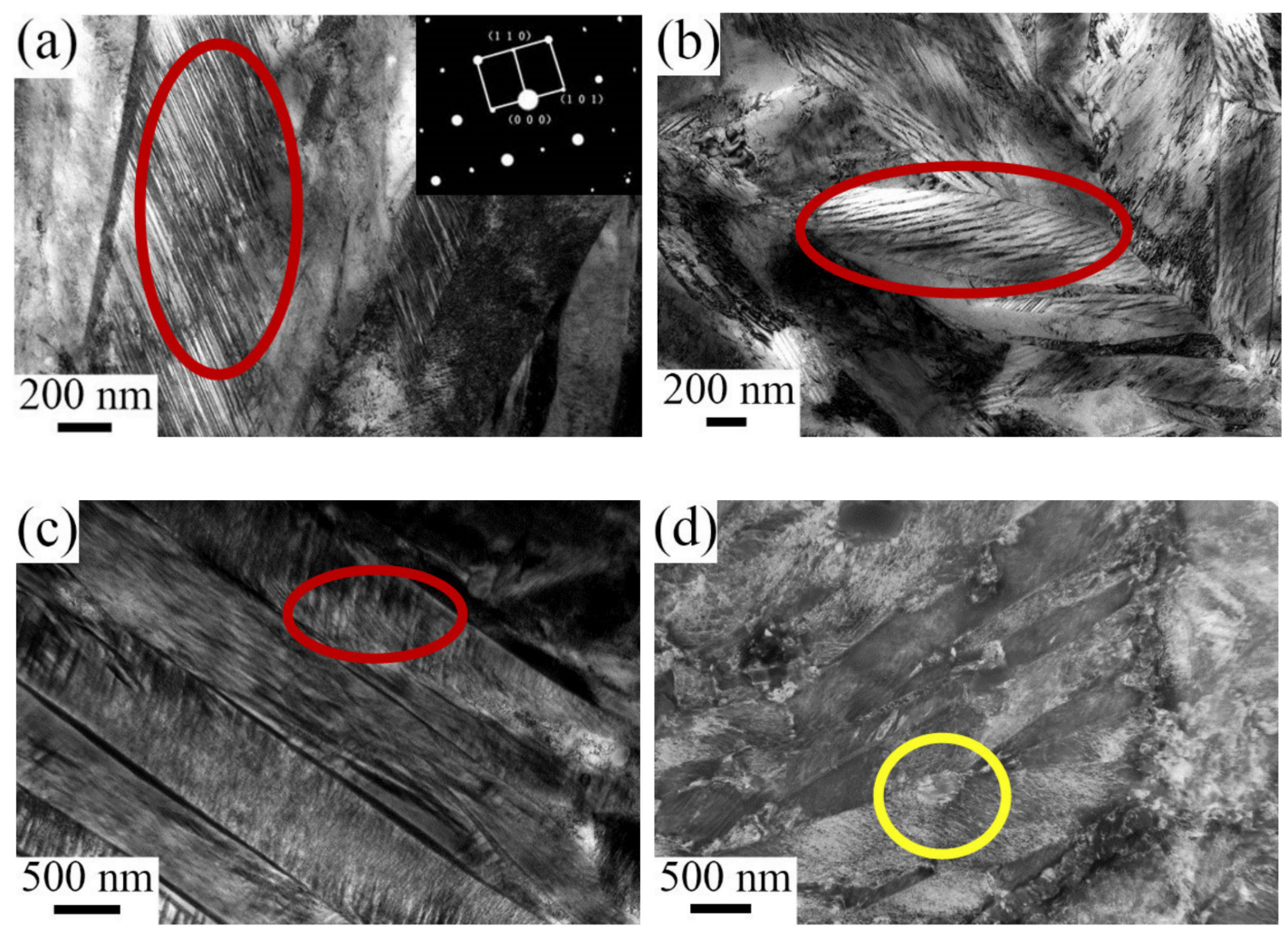

Figure 12. TEM microstructure of UHCS-4Al after tempering at different temperatures. (a) $160^{\circ} \mathrm{C},(\mathbf{b}) 360^{\circ} \mathrm{C},(\mathbf{c}) 400{ }^{\circ} \mathrm{C}$, (d) $480{ }^{\circ} \mathrm{C}$.
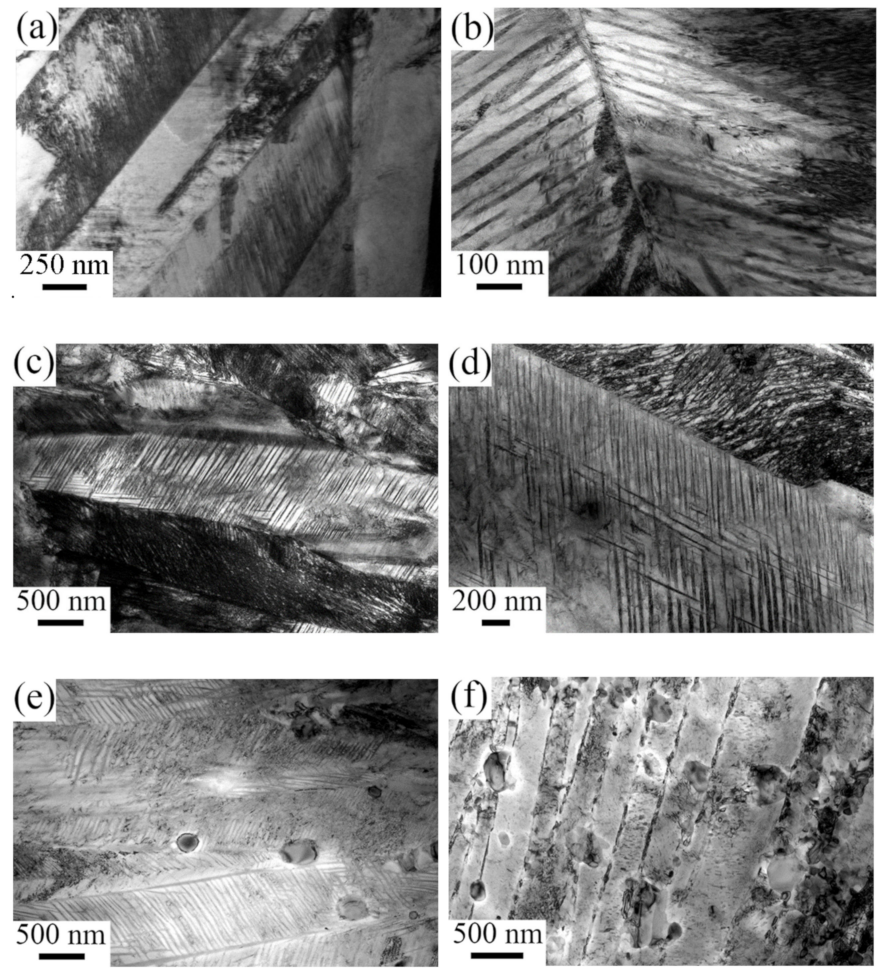

Figure 13. TEM microstructure of UHCS-6Al after tempering at different temperatures. (a) $160{ }^{\circ} \mathrm{C}$, (b) $360{ }^{\circ} \mathrm{C}$, (c) $440{ }^{\circ} \mathrm{C}$, (d) $480{ }^{\circ} \mathrm{C}$, (e) $520{ }^{\circ} \mathrm{C}$, (f) $560{ }^{\circ} \mathrm{C}$. 


\section{Conclusions}

The effects of the addition of aluminum on the microstructure and properties of ultrahigh-carbon bearing steel alloys were studied during tempering with temperatures as high as $500^{\circ} \mathrm{C}$. It was revealed that both microstructure and properties were significantly different from the coventional high-carbon bearing steel, such as relative low density, extra-high hardness and high temperature resistance. The main conclusions of this study are as follows.

(1) The addition of Al significantly reduced the density of steel, inhibited the precipitation of carbide networks and significantly improved the phase transition temperature of ultra-high-carbon steel.

(2) UHCS-2Al, UHCS-4Al and UHCS-6Al austenitized at $825^{\circ} \mathrm{C}, 850{ }^{\circ} \mathrm{C}$ and $875{ }^{\circ} \mathrm{C}$, respectively, and at low-tempering temperature, the hardness peaks were between 65-68 HRC, and such a high hardness was beneficial for the wear-resistance and fatigue properties.

(3) The addition of Al significantly improved the tempering stability and temperature resistance of ultra-high-carbon steel, as the addition of $\mathrm{Al}$ inhibited the process of $\varepsilon$-carbide transforming into granular cementite, leading to the failure of martensite to decarbonize to form ferrite. In addition, the greater the amount of added $\mathrm{Al}$, the better the tempering stability and temperature resistance of ultra-high-carbon steel.

Author Contributions: Conceptualization, J.B.; Data curation, J.B., W.Z., Z.S., H.W. and W.C.; Funding acquisition, Z.S. and W.C.; Investigation, J.B.; Methodology, Z.S.; Writing-original draft, J.B.; Writing-review \& editing, Y.W., C.W. and X.C. All authors have read and agreed to the published version of the manuscript.

Funding: This research is supported by the Central Iron and Steel Research Institute independently invested in a special research and development fund (No.shi20T61200ZD, National Natural Science Foundation of China (NSFC) (Nos. 51871062 and 51871194).

Institutional Review Board Statement: Not applicable.

Informed Consent Statement: Not applicable.

Data Availability Statement: The data presented in this study are available on request from the corresponding author.

Acknowledgments: The authors want to thank the College of Materials Science and Engineering of Chongqing University and Central Iron \& Steel Research Institute for the supply of material and technical support in this work.

Conflicts of Interest: The authors declare no conflict of interest.

\section{References}

1. Sherby, O.D.; Walser, B.; Young, C.M.; Cady, E.M. Superplastic ultra-high carbon steels. Scr. Metall. 1975, 9, 569-573. [CrossRef]

2. Lesuer, D.R.; Syn, C.K.; Goldberg, A.; Wadsworth, J.; Sherby, O.D. The case for ultrahigh-carbon steels as structural materials. JOM 1993, 45, 40-46. [CrossRef]

3. Syn, C.K.; Lesuer, D.R.; Sherby, O.D. Enhancing tensile ductility of a particulate-reinforced aluminum metal matrix composite by lamination with Mg-9\%Li alloy. Mater. Sci. Eng. A 1996, 206, 201-207. [CrossRef]

4. Suna, H.; Wadsworth, J.; Lin, J.; Sherby, O.D. Mechanical prperties and microstructure of heat-treated ultrahigh carbon steels. Mater. Sci. Eng. 1979, 38, 35-40. [CrossRef]

5. Tsuzaki, K.; Sato, E.; Furimoto, S.; Maki, T. Formation of an $(\alpha+\theta)$ microduplex structure without thermomechanical processing in superplastic ultrahigh carbon steels. Scr. Mater. 1999, 40, 675-681. [CrossRef]

6. Özdemir, N.; Orhan, N. Investigation on the superplasticity behavior of ultrahigh carbon steel. Mater. Design 2006, 27, 706-709. [CrossRef]

7. Hecht, M.D.; Webler, B.A.; Picard, Y.N. Digital image analysis to quantify carbide networks in ultrahigh carbon steels. Mater. Charact. 2016, 117, 134-143. [CrossRef]

8. Decost, B.L.; Francis, T.; Holm, E.A. Exploring the microstructure manifold: Image texture representations applied to ultrahigh carbon steel microstructures. Acta. Mater. 2017, 133, 30-40. [CrossRef] 
9. Hong-Juan, L.I.; Wang, B.Q.; Song, X.Y.; Guo, S.Z.; Gu, N.J. New spheroidizing technique of ultra-high carbon steel with aluminum addition. J. Iron Steel Res. 2006, 13, 9-13.

10. Zhang, Z.L.; Liu, Y.N.; Zhu, J.W.; Yu, G. Processing and properties of ultrahigh-carbon (1.6\%C) steel. Mater. Sci. Eng. A 2008, 483, 64-66. [CrossRef]

11. Oyama, T.; Sherby, D.; Wadsworth, J.; Walser, B. Application of the divorced eutectoid transformation to the development of fine-grained, spheroidized structures in ultrahigh carbon steels - Science Direct. Scr. Metall. 1984, 18, 799-804. [CrossRef]

12. Taleff, E.M.; Syn, C.K.; Lesuer, D.R.; Sherby, O.D. Pearlite in ultrahigh carbon steels: Heat treatments and mechanical properties. Metall. Mater. Trans. A 1996, 27, 111-118. [CrossRef]

13. Syn, C.K.; Lesuer, D.R.; Sherby, O.D. Influence of microstructure on tensile properties of spheroidized ultrahigh-carbon (1.8 Pct C steel). Metall. Mater. Trans. A 1994, 25, 1481. [CrossRef]

14. Sherby, O.D.; Oyama, T.; Kum, D.W.; Walser, B.; Wadsworth, J. Ultrahigh carbon steels. JOM 1985, 37, 50-56. [CrossRef]

15. Hecht, M.D.; Picard, Y.N.; Webler, B.A. Effects of Cr concentration on cementite coarsening in ultrahigh carbon steel. Metall. Mater. Trans. A 2019, 50, 4779-4790. [CrossRef]

16. Hecht, M.D.; Webler, B.A.; Picard, Y.N. Effects of Nb modification and cooling rate on the microstructure in an ultrahigh carbon steel. Metall. Mater. Trans. A 2018, 49, 2161-2172. [CrossRef]

17. Chen, X.M.; Liu, Y.N.; Zhu, J.W.; Ge, L.L. Tribological behavior of $1.41 \mathrm{wt} \% \mathrm{C}$ ultrahigh-carbon steel with quenching and low-temperature tempering treatment. Tribol. Lett. 2010, 38, 79. [CrossRef]

18. Liu, H.D.; Sun, J.J.; Jiang, T.; Guo, S.W.; Liu, Y.N.; Lin, X. Rolling contact fatigue behavior of an ultrahigh carbon steel. Acta. Metall. Sin. 2014, 12, 1446.

19. Liu, H.J.; Sun, J.J.; Jiang, T.; Guo, S.W.; Liu, Y.N. Improved rolling contact fatigue life for an ultrahigh-carbon steel with nanobainitic microstructure. Scr. Mater. 2014, 90-91, 17-20. [CrossRef]

20. Ren, P.; Chen, X.P.; Cao, Z.X.; Mei, L.; Li, W.J.; Cao, W.Q.; Liu, Q. Synergistic strengthening effect induced ultrahigh yield strength in lightweight Fe 30Mn 11Al-1.2C steel. Metall. Mater. Trans. A 2019, 752, 160-166. [CrossRef]

21. Chen, S.P.; Rana, R.; Haldar, A.; Ray, R.K. Current state of Fe-Mn-Al-C low density steels. Prog. Mater. Sci. 2017, 89, 345-391. [CrossRef]

22. Kim, S.H.; Kim, H.; Kim, N.J. Brittle intermetallic compound makes ultrastrong low-density steel with large ductility. Nature 2015, 518, 77-79. [CrossRef]

23. Wang, H.; Chen, Q.M.; Zhang, W.L.; Wang, C.; Yu, F.; Cao, W.Q. Continuous cooling transformation of an ultrahigh carbon steel. Heat Treat. Metals. 2017, 42, 24-28.

24. Chen, W.; Li, L.F.; Yang, W.Y.; Sun, Z.Q. Effects of Aluminum on the microstructures of transformation during slow cooling and dynamic phase transformation of undercooled austenite of hypereutectoid steel. Acta Metall. Sin. 2008, 44, $1069-1975$. 